\title{
Uji Sitotoksisitas Ekstrak Pektin Limbah Kulit Buah Kopi Robusta (Coffea canephora) pada Kultur Sel Fibroblas Pulpa Gigi Manusia (Cytotoxicity Effect of Pectin Extract from Coffea Robusta (Coffea canephora) Fruit Peels on Human Dental Pulp Fibroblasts Cell Culture)
}

\author{
Kharishah Muslihah, Agus Sumono, Dwi Warna Aju Fatmawati \\ Fakultas Kedokteran Gigi Universitas Jember \\ Jalan Kalimantan No. 37, Kampus Bumi Tega Boto Jember 68121 \\ e-mail : kharishahmuslihah@gmail.com
}

\begin{abstract}
Background: Coffee has a by-product (waste product) that generated from coffee processing. Coffee fruit's peels contains active compound, that is pectin. Pectin has several benefits in health, as a regeneration of hard and soft tissue that can be applied in dentistry and pectin has the potential as an anti-cancer substance. Pectin as a biomaterial must have biocompability. Biocompatibility of the material can be tested by cytotoxicity test by MTT method on human dental pulp fibroblasts cell culture. Objective: To know the toxicity of extract pectin from coffee robusta fruit peels on human dental pulp fibroblasts cell culture. Method: This research is a experimental laboratory with post-test only control group design. Culture of fibroblast cells at the well was exposed by pectin extract for 24 hours, then each well was given MTT and incubated for 4 hours. The effects of cytotoxicity were measured by calculating cell viability (\%). Data were analyzed using Probit test, One-way ANOVA followed by LSD. Result: Each group has a cell viability value above 50\%. Conclusion: Extract pectin from Robusta coffee fruit peel's had no cytotoxic effect on human dental pulp fibroblsts cell culture
\end{abstract}

Keywords: coffe robusta fruit peels, cytotoxicity, human pulp fibroblst cell culture, pectin

\begin{abstract}
Abstrak
Latar Belakang: Kulit buah kopi merupakan produk samping (limbah) yang dihasilkan dari proses pengolahan kopi. Kulit buah kopi mengandung senyawa aktif berupa pektin. Pektin mempunyai beberapa manfaat dibidang kesehatan, yaitu sebagai bahan regenerasi jaringan keras maupun lunak yang dapat diaplikasikan di bidang kedokteran gigi serta pektin mempunyai potensi sebagai zat anti kanker. Pektin sebagai biomaterial harus bersifat biokompatibel. Biokompatibilitas bahan dapat diuji melalui uji sitotoksisitas dengan metode MTT pada kultur sel fibroblas pulpa gigi manusia. Tujuan: Untuk mengetahui toksisitas ekstrak pektin kulit buah kopi robusta pada kultur sel fibroblas pulpa gigi manusia. Metode: Penelitian ini merupakan penelitian laboratoris dengan rancangan post-test only control group design. Kultur sel fibroblas pada sumuran dipapar dengan ekstrak pektin selama 24 jam, lalu tiap sumuran diberi MTT dan diinkubasi selama 4 jam. Efek sitotoksisitas diukur dengan menghitung viabilitas sel (\%). Data dianalisis menggunakan uji Probit, One-way ANOVA dilanjutkan LSD. Hasil: Setiap kelompok memeiliki nilai viabilitas sel diatas $50 \%$. Kesimpulan: Ekstrak pektin kulit buah kopi robusta tidak toksik terhadap kultur sel fibroblas pulpa gigi manusia.
\end{abstract}

Kata kunci: Kulit buah kopi, kultur sel fibroblas pulpa, pektin, sitotoksisitas 


\section{Pendahuluan}

Indonesia menjadi salah satu penghasil kopi terbesar didunia. Produksi kopi dalam negeri selalu mengalami kenaikan tiap tahun, terhitung dari tahun 2014 hingga tahun 2016. Semakin meningkatnya jumlah produksi kopi maka semakin tinggi pula produk samping yang dihasilkan. Proses pengolahan kopi akan menghasilkan limbah atau hasil samping yang berupa kulit buah kopi. Hingga saat ini kulit buah kopi belum banyak dimanfaatkan padahal kulit buah kopi mengandung senyawa aktif berupa pektin $[1,2]$.

Pektin adalah suatu senyawa heteropolisakarida yang secara umum terdapat pada dinding sel primer tanaman. Senyawa pektin dapat berfungsi sebagai perekat antara dinding sel yang satu dengan yang lainnya. Berdasarkan penelitian Varoni dkk (2012) pektin merupakan biomaterial yang memiliki potensi yang baik untuk regenerasi jaringan lunak maupun keras. Pektin juga mampu mempercepat penyembuhan luka yang lebih cepat yang diuji coba pada pig skin (Chansiripornchai dkk, 2005). Serta pektin memiliki daya antioksidan yang dapat mengikat radikal bebas dan molekul yang sangat reaktif dalam tubuh sehingga dapat mencegah kerusakan sel dalam tubuh. Penelitian yang dilakukan Rizki dkk (2015) juga menyatakan bahwa ekstrak pektin kulit buah kakao mempunyai potensi aktivitas anti kanker [3,4,5,p16]

Sebagain penelitian telah menyebutkan bahwa pektin merupakan kandidat biomaterial yang mempunyai banyak keuntungan dan manfaat di bidang kedokteran, namun hingga saat ini belum ada penelitian tentang pengaruh pektin terhadap sel normal rongga mulut apakah bahan tersebut dapat diterima jaringan dan tidak bersifat toksik, untuk mengetahui biokompatibilitas tersebut dapat dilakukan dengan pemeriksaan invitro yaitu uji sitotoksisitas. Uji sitotoksisitas bahan dapat dilihat dengan melakukan pengukuran terhadap viabilitas sel dalam kultur. Kultur sel yang digunakan adalah kultur sel fibroblas yang diambil dari pulpa gigi manusia [6].

Metode yang umum digunakan untuk uji sitotoksisitas adalah dengan metode MTT assay. Uji MTT sangat sensitif untuk mengevaluasi viabilitas sel. Kelebihan MTT assay adalah valid dan relatif lebih cepat. Garam methylthiazol tetrazolium (MTT) akan direduksi oleh sel hidup menjadi endapan formazan berwarna ungu dan jumlahnya sebanding dengan jumlah sel hidup [7].
Berdasarkan latar belakang diatas, penulis ingin melakukan penelitian tentang sitotoksisitas ekstrak pektin kulit buah kopi robusta terhadap kultur sel fibroblas pulpa gigi manusia.

\section{Metode Penelitian}

Jenis penelitian ini adalah eksperimental laboratoris dengan rancangan penelitian the post only control group design. Penelitian dilakukan di Laboratorium Parasitologi Fakultas Kedokteran Universitas Gadjah Mada.

Proses uji sitotoksisitas yaitu sel fibroblas didistribusikan kedalam 24 sumuran. Tiap sumuran berisi sel fibroblas dan media kultur DMEM dengan kepadatan 3x104 sel/ml sebanyak $250 \mu \mathrm{l}$. kemudian diinkubasi selama 24 jam dengan suhu $37^{\circ} \mathrm{C}$. Sel fibroblas diamati dibawah mikroskop inverted, jika sel sudah memenuhi lalu ditambahkan ekstrak pektin pada sumuran. Ekstrak pektin sebanyak $100 \mu \mathrm{l}$ dengan konsentrasi 100, 50, 25, 12.5, 6.25, $3.125,1.562$ dan $0.781 \mu \mathrm{g} / \mathrm{ml}$ dimasukkan pada setiap sumuran dan masing-masing konsentrasi sebanyak 3 sumuran. Setelah itu diinkubasi selama 24 jam. Setelah diinkubasi ditambahkan reagen MTT sebanyak $5 \mathrm{mg} / \mathrm{ml}$. Sel diinkubasi kembali selama 4 jam dalam inkubator $\mathrm{CO} 2$ $5 \%$, pada suhu $37^{\circ} \mathrm{C}$.

Reaksi MTT dihentikan dengan stopper reagent (SDS $10 \%$ dalam $0.1 \mathrm{~N} \mathrm{HCL}$ ) dan diinkubasi dalam suhu ruang selama 24 jam. Absorbansi kemudian dibaca dengan menggunakan ELISA reader pada $\lambda 595 \mathrm{~nm}$. Hasil yang diperoleh dinyatakan dalam optical density (OD). Hasil tersebut kemudian dikonversi ke dalam rumus persentase viabilitas sel. Hasil persen kehidupan sel (viabilitas) di masukkan dalam analisis probit untuk menghitung IC50

$\%$ Viabilitas Sel =

Absorbansi tes - Absorbansi media $\times 100 \%$ Absorbansi sel - Absorbansi media

\section{Hasil Penelitian}

Hasil penelitian diperoleh nilai rata-rata presentase kehidupan sel seperti pada tabel berikut ini. 


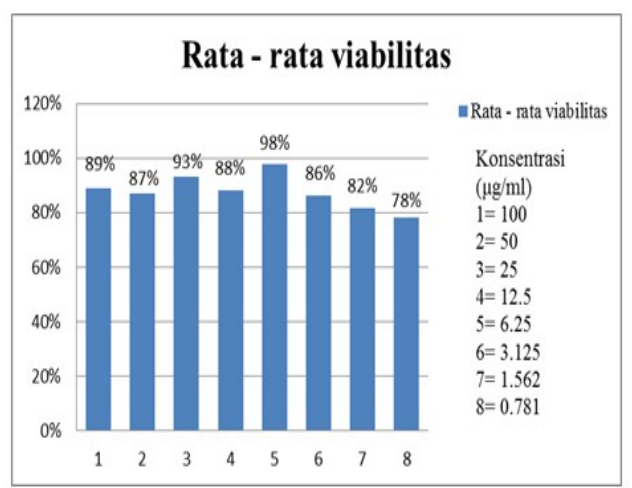

Gambar 1. Histogram rata-rata viabilitas pada semua konsentrasi.

Semua konsentrasi memiliki nilai viabilitas yang melebihi $50 \%$. Presentase viabilitas tertinggi pada konsentrasi $6.25 \mu \mathrm{l}$ dan terendah ada konsentrasi $0.781 \mu \mathrm{l}$.

Data hasil rata-rata presentase viabilitas sel lalu di hitung inhibition concentration (IC 50) menggunakan analisis probit. Didapatkan hasil seperti pada tabel berikut

Tabel 1. Hasil IC 50 pada analisis probit

\begin{tabular}{lc}
\hline Probabilitas & Konsentrasi \\
\hline 0.5 & 0.00 \\
\hline
\end{tabular}

Hasil analisis probit pada tabel 1 menunjukkan bahwa Nilai IC50 yang diperoleh sebesar $0,00 \mu \mathrm{g} / \mathrm{ml}$, yang artinya tidak ada konsentrasi yang menghambat $50 \%$ kehidupan sel.

Data selanjutnya dilakukan uji normalitas Hasil uji normalitas menunjukkan 0.982 , nilai $p>0.05$ yang artinya data tersebut terdistribusi normal, dilanjutkan dengan uji homogenitas varian Levene test dengan nilai signifikansi sebesar $0.672(p>0.05)$ sehingga data tersebut homogen. Data yang terdistribusi normal dan homogen sehingga dilanjutkan uji parametrik Oneway Anova.

Uji one way Anova yang telah diolah didapatkan hasil tingkat kemaknaan nilai signifikansi sebesar $0.042(p<0.05)$ yang berarti terdapat perbedaan pada seluruh kelompok dalam penilitian. Uji statistik dilanjutkan dengan uji LSD, Konsentrasi 25 memiliki perbedaan bermakana dengan konsentrasi 1.562 dan 0.781 , serta pada konsentrasi 6.25 berbeda bermakna dengan konsertasi 3.125, 1.562 dan 0.78 .

\section{Pembahasan}

Hasil penelitian uji sitotoksisitas pada sel fibroblas pulpa gigi manusia terlihat bahwa ratarata persen sel hidup (viabilitas) pada semua kelompok konsentrasi lebih dari $50 \%$. Oleh karena itu ekstrak pektin limbah kulit buah kopi robusta dapat dikatakan tidak toksik berdasarkan parameter toksisitas (IC50), yang artinya suatu biomaterial dikatakan tidak toksik apabila presentase sel hidup setelah terpapar bahan lebih dari $50 \%[8]$.

Hal ini juga didukung dengan hasil perhitungan IC50 yang didapatkan yaitu sebesar 0,00 $\mu \mathrm{g} / \mathrm{ml}$. Nilai IC50 yaitu nilai untuk menunjukkan konsentrasi ekstrak pektin yang dapat menghambat hingga $50 \%$ kehidupan sel fibroblas pulpa manusia. Nilai $0,00 \mu \mathrm{g} / \mathrm{ml}$ menunjukkan bahwa tidak ada konsentrasi ekstrak pektin kulit buah kopi robusta yang memberikan efek penghambatan pada $50 \%$ pertumbuhan sel fibroblas pulpa gigi manusia. Hal ini sesuai dengan penelitian Chansiripornchai dkk (2005) yang menunjukkan bahwa polisakarida pektin yang berasal dari kulit durian bersifat biokompatibel dan tidak menunjukkan efek toksik pada jaringan tubuh. Pektin dari kulit durian tersebut justru berperan dalam mempercepat proses penyembuhan yang diuji coba pada pig skin [9].

Hasil uji LSD menunjukkan pada konsentrasi $25 \mu \mathrm{g} / \mathrm{ml}$ memiliki perbedaan signifikan dengan konsentrasi $1.562 \mu \mathrm{g} / \mathrm{ml}$ dan 0.781 $\mu \mathrm{g} / \mathrm{ml}$, konsentrasi $6.25 \mu \mathrm{g} / \mathrm{ml}$ berbeda signifikan dengan konsentrasi $3.125 \mu \mathrm{g} / \mathrm{ml}, 1.562 \mu \mathrm{g} / \mathrm{ml}$ dan $0.781 \mu \mathrm{g} / \mathrm{ml}$ dan konsentrasi yang lain tidak memberikan perbedaan yang signifikan. Tidak ada perbedaan yang signifikan tersebut karena pektin merupakan bahan yang tidak toksik terhadap kultur sel fibroblas pulpa gigi manusia, sehingga meskipun sel fibroblas dipapar pektin dengan berbagai konsentrasi persentase kehidupan sel tetap tinggi yaitu diatas $50 \%$. Ekstrak pektin dengan konsentrasi $6.25 \mu \mathrm{g} / \mathrm{ml}$ dan $25 \mu \mathrm{g} / \mathrm{ml}$ diduga merupakan konsentrasi efektif yang tidak menimbulkan efek toksik pada sel fibroblas pulpa manusia, terlihat dari jumah sel hidup pada konsentrasi tersebut paling tinggi yaitu sebesar $93 \%$ dan $97 \%$. Senyawa pektin memiliki aktivitas antioksidan. Antioksidan pada pektin dapat mengikat radikal bebas dan molekul yang sangat reaktif dalam tubuh sehingga kerusakan sel dapat dicegah. Antioksidan dapat menghentikan proses perusakan sel dengan cara memberikan elektron kepada radikal bebas sehingga radikal bebas tidak mempunyai kemampuan mencuri elektron dari 
sel dan DNA. Pencegahan kerusakan sel ini akan menyebabkan banyaknya jumlah sel hidup sehingga pada penelitian ini, jumlah sel fibroblas yang hidup setelah dipapar pektin jumlahnya cukup tinggi [4]/

Pektin mempunyai potensi sebagai zat anti kanker, dengan kemampuanya yang dapat menghambat metastasis sel kanker kolon sesuai penelitian Rizki dkk (2015). Pektin sebagai zat anti kanker diduga berhubungan dengan peran galektin-3 pada sel kanker. Galektin-3 merupakan protein dalam sel yang berperan dalam berbagai fungsi seluler salah satunya yaitu proses proliferasi, diferensiasi serta galektin-3 terlibat dalam proses metastasis. Galektin-3 mengalami over ekspresi dan jumlahnya relatif lebih banyak pada sel kanker. Pektin sebagai zat anti kanker tersebut mampu menghambat fungsi galektin-3 pada sel kanker. Pektin menghambat fungsi galektin-3 dengan menghambat pengikatan galektin pada $\beta$-galaktoside permukaan sel kanker. Terhambatnya fungsi galektin-3, sehingga menyebabkan metastasis pada sel kanker juga terhambat. Pektin juga dapat memicu kematian sel melalui jalur apoptosis pada sel kanker, terhambatnya fungsi galektin-3 pada sel kanker memicu galektin-3 untuk mengaktifkan sinyal apoptosis pada mitokondria, selanjutnya mitokondria akan mengarahkan pelepasan sitokrom c yang diikuti dengan aktivasi caspase 3 sehingga menimbuIkan apoptosis [10,11]

Sedangkan pada sel normal pektin tidak menghambat dan tidak mempengaruhi fungsi dari galektin-3 sehingga galektin-3 tetap dapat berperan secara normal dalam berbagai fungsi selulernya dan tidak adanya penghambatan fungsi galektin-3 pada sel normal sehingga galektin-3 tidak memicu apoptosis (kematian sel) pada sel normal. Adanya apoptosis (kematian sel) pada sel kanker menandakan bahwa pektin bersifat toksik pada sel kanker dan tidak bersifat toksik pada sel normal [12].

Pektin juga mempunyai efek sebagai anti inflamasi. Efek anti inflamasi pada pektin didasarkan pada pengaruh pektin terhadap aktivitas fungsional leukosit. Pektin dapat menurunkan jumlah neutrophil pada proses inflamasi. Pada jaringan dengan jumlah neutrophil yang lebih sedikit diduga dapat mempercepat penyembuhan luka. Hal ini disebabkan neutrophil menghasilkan enzim neutrophil proteasae elastasae dan proteinasae-3 yang mempunyai kemampuan memecah elastin dan matriks ekstra seluler. Gangguan pada matriks ekstra seluler dapat mengganggu perbaikan epitel dan dapat menghambat proses penyembuhan luka. Sehingga diharapkan menurunya jumlah sel neutrophil dapat mempercepat proses penyembuhan luka [15].

Viabilitas sel yang ditunjukkan dalam penelitian ini akibat pengaruh ekstrak pektin kulit buah kopi robusta menunjukkan tidak adanya efek toksik pada sel fibroblas pulpa manusia. Hal ini ditunjukkan dengan persentase viabilitas sel yang lebih dari $50 \%$. Berdasarkan penjelasan beberapa peniliti, pektin diduga memiliki beberapa manfaat dibidang kesehatan yaitu memiliki aktivitas antioksidan serta anti inflamasi sehingga mampu menekan kematian sel. Diharapkan senyawa ini memiliki arti luas dibidang kesehatan dan digunakan untuk pengobatan beberapa penyakit umum.

\section{Simpulan dan Saran}

Ekstrak pektin limbah kulit buah kopi robusta merupakan ekstrak yang tidak toksik terhadap kultur sel fibroblas pulpa manusia. Persentase sel hidup (viabilitas sel) paling tinggi pada konsentrasi $6.25 \mu \mathrm{l}$. Perlu adanya penelitian lebih lanjut untuk mengetahui mekanisme viabilitas sel dan respon sel terhadap ekstrak pektin kulit buah kopi robusta menggunakan parameter yang lain. Perlu adanya penelitian lebih lanjut meliputi uji biokompatibilitas secara in vivo atau uji klinis untuk mengetahui efek pektin kulit buah kopi robusta secara lengkap.

\section{Daftar Pustaka}

[1] Kemenperin. 2013. Produksi Kopi Nusantara Ketiga Terbesar di Dunia. http://www.kemenperin.go.id/artikel/6611/Produk-

si-Kopi-Nusantara-Ketiga-Terbesar-Di-Dunia [diakses tanggal 2 Januari 2017].

[2] Dofir, M. 2016. Produksi Kopi Jatim Meningkat, Areal Bahan Terus Diperluas.p.1 https://www.suarajatimpost.com/read/3473/20 161215/144853/produksi-kopi-jatim-meningkat-areal-lahan-terus-diperluas/ [Diakses pada 28 Februari 2017

[3] Srivastava, Pranati and Rishabha, Malviya. 2011. Sources of pectin, extraction and it's application in pharmaceutical industry-An overview. Indian Journal of Natural Products and Resources. Vol.2 10-18 
[4] Hawach Venicia, Marie-Anne Boujaoude, and Roula M. Abdel-Massih. 2016. The Cytotoxic and Anti-proliferative Activity of High Molecular Weight Pectin and Modified Citrus Pectin. Functional Foods in Health and Disease; 6(9): 587-601

[5] Sayuti, K, dan Yenrina, R. 2015. Antioksidan, Alami dan Sintetik. Padang : Andalas University Press. p.16

[6] Emilda, Y., E. Budiparman, dan S. Kuntari. 2014. Uji toksisitas ekstrak bawang putih Allium Sativum terhadap kultur sel fibroblast. Dental Journal. 7: 215

[7] Siregar. F., B. Hadijono. 2000. Uji Sitotoksisitas Dengan MTT Esei. Jurnal Kedokteran Gigi Universitas Indonesia. 7: 29-30

[8] Rogero SO, Malmonge SM, Lugao AB, Ikeda TI, Miyamaru, I, Cruz AS. 2003. Biocompability Study of Polymeric Biomaterials. J Arif Organs 27(5): 424-427

[9] Chansiripornchai P., C. Pramatwinai dan A.. Rungsipipat, 2005. The Efficiency of Polysaccahride Gel Extra from Fruit-Hulls of Durian for Wound Healing in Pig Skin. Acta Hort. Vol. 5(3): 39

[10] Rizki, K. P., W. Rochmah dan G. Nandan. 2015. Aktivitas Antikanker Pektin Kulit Buah Kakao Terhadap Jumlah Sel Goblet Kolon. IJPST. 2.(3): 81

[11] Nangia-Makker, P., S. Nakahara., V. Hogan, dan A. Raz. 2007. Galectin-3 in apoptosis, a novel therapeutic target. J Bioenerg Biomembr. 39:79-83

[12] Sathisha, U V, Smitha Jayaram, M. A. Harish Nayaka, Shylaja M. Dharmesh. 2007. Inhibition of galectin-3 mediated cellular interactions by pectic polysaccharides from dietary sources. Glycoconj J Springer Science. 24:497-507

[13] Deters, A. M., K. Schro, dan A. Hensel. 2005. Kiwi Fruit (Actinidia chinensis L.) Polysaccharides Exert Stimulating Effects on Cell Proliferation via Enhanced Growth Factor Receptors, Energy Production, and Collagen Synthesis of Human Keratino- cytes, Fibroblasts, and Skin Equivalents.Journal Of Celluler Physiology. 202:720.

[14] Deters, A., J. Zippel, N. Hellenbrand, D. Pappai, C. Possemeyer, dan A. Hensel. 2010. Aqueous extracts and polysaccharides from Marshmallow root (Althea officinalis L.): Cellular internalisation and stimulation of cell physiology of human epithelial cells in vitro. Journal of Ethnopharmacology. 127: 67

[15] Markov, P.A., S. V. Popov., I. R. Nikitina., R. G. Ovodova, dan Y. S. Ovodov. 2010. Anti Inflammatory Activity of Pectins and Their Galacturonan Backbone. Russian Journal of Bioorganic Chemistry. 37(7): 819

[16] Varoni, E. M., M. Iriti, dan L. Rimondini. 2012. Plant Products for Innovative Biomaterials in Dentistry. Journal Coatings: 182. www.mdpi.com/journals/coatings [ Diakses pada 10 Desember 2016) 
Muslihah, et al., Uji Sitotoksisitas Ekstrak Pektin Limbah Kulit Buah Kopi Robusta pada Kultur Sel... 